\title{
Pengaruh Model SFAE Berorientasi Tri Hita Karana Terhadap Hasil Belajar IPA
}

\author{
I G. N. Pt. Adi Laksana Putra ${ }^{1 *}$ \\ Jurusan PGSD, FIP Universitas Pendidikan Ganesha Singaraja, Indonesia
}

\author{
A R T I C L E I N F O \\ Article history: \\ Received 10 February \\ 2019 \\ Received in revised form \\ 09 March 2019 \\ Accepted 15 April 2019 \\ Available online 25 May \\ 2019 \\ Kata Kunci: \\ IPS, Problem Based \\ Learning, Role Pyaing \\ Motivasi, Hasil Belajar. \\ Keywords: \\ Social Science, Problem \\ Based Learning, Rolle \\ Pyaing, the motivation, the \\ results of the study.
}

\begin{abstract}
A B S T R A K
Penelitian ini bertujuan untuk mengetahui perbedaan yang signifikan pada hasil belajar IPA siswa yang dibelajarkan dengan model Student Facilitator and Explaining (SFAE) Berorientasi Tri Hita Karana dan siswa yang dibelajarkan tidak dengan model Student Facilitator and Explaining (SFAE) Berorientasi Tri Hita Karana pada kelas V Sekolah Dasar di Gugus XV Kecamatan Buleleng Tahun Pelajaran 2017/2018. Penelitian ini termasuk penelitian eksperimen semu yang menggunakan desain non-equivalent post-test only control group design. Populasi penelitian adalah seluruh siswa kelas V di Gugus XV Kecamatan Buleleng, sampel penelitian adalah siswa kelas $V$ di SD Negeri 2 Kalibukbuk sebagai kelas eksperimen dan siswa kelas V di SD Negeri 3 Anturan sebagai kelas kontrol. Pengumpulan data dalam penelitian ini menggunakan metode tes. Bentuk tes yang digunakan berupa objektif pilihan ganda. Data yang didapatkan dianalisis dengan teknik analisis statistik deskriptif dan statistik inferensial (uji-t). Hasil analisis menunjukan rata-rata skor hasil belajar IPA siswa yang menggunakan model pembelajaran SFAE berorientasi Tri Hita Karana sebesar 23,12.
\end{abstract} Sedangkan rata-rata skor hasil belajar IPA siswa yang tidak menggunakan model SFAE berorientasi Tri Hita Karana sebesar 16,21. Pengujian hipotesis menggunakan uji-t menunjukan $t_{\text {hitung }}>t_{\text {tabel }}$ ( $t_{\text {hitung }}=$ $6,821>$ tabel=1,99962). Berdasarkan hasil penelitian dapat disimpulkan bahwa terdapat perbedaan yang signifikan hasil belajar IPA siswa yang dibelajarkan melalui model Student Facilitator and Explaining (SFAE) berorientasi Tri Hita Karana dan siswa yang dibelajarkan tidak melalui model Student Facilitator and Explaining (SFAE) berorientasi Tri Hita Karana pada kelas V Sekolah Dasar di Gugus XV Kecamatan Buleleng Tahun Pelajaran 2017/2018.

\section{A B S T R A C T}

This study aimed at investigating the effect of Student Facilitator and Explaining (SFAE) technique based on Tri Hita Karana towards students' science achievement in fifth grade of Buleleng district primary schools cluster XV academic year 2017/2018. This study was an experimental study utilizing non-equivalent post-test only control group design. The population of this study was fifth graders of Buleleng district primary schools cluster XV and the sample of this study was fifth graders of $S D$ Negeri 2 Kalibukbuk as the experimental group and fifth graders of SD Negeri 3 Anturan as the control group. The data collection was utilizing instrument in the form objective test. Then, the obtained data was analysis using both descriptive and inferential (t-test) statistical analysis. The result showed that there was a difference of mean score between both groups. The mean score for experimental group was 23,12 while the mean score for control group was 16,21. Furthermore, hypothesis testing showed that $t_{o b s}>t_{c v}\left(t_{o b s}=6,821>t_{c v}=1,99962\right)$. Based on the result of the study, it can be concluded that there was a significant difference on students' science achievement between the students taught using Student Facilitator and Explaining (SFAE) technique based on Tri Hita Karana and the students taught without Student Facilitator and Explaining (SFAE) technique based on Tri Hita Karana at fifth graders of Buleleng district primary schools cluster XV academic year 2017/2018

Copyright @ Universitas Pendidikan Ganesha. All rights reserved. 


\section{Pendahuluan}

Ilmu pengetahuan alam merupakan suatu ilmu yang mempelajari alam beserta isinya. Pelajaran IPA sangat digemari oleh siswa karena materinya berkaitan dengan peristiwa alam, lingkungan, mahkluk hidup, dan alam beserta isinya. Bundu (dalam Virani, Riastini, \& Suarjana, 2016) menyatakan, secara harfiah, sains dapat disebut sebagai ilmu pengetahuan tentang alam atau ilmu pengetahuan yang mempelajari peristiwa-peristiwa yang terjadi di alam. Tujuan utama dalam mempelajari mata pelajaran ini adalah untuk memahami berbagai rahasia alam yang terjadi di lingkungan sekitar dan menjaga atau melestarikan alam beserta isinya.

Seperti yang terjadi akhir-akhir ini sering terjadi peristiwa alam yang diakibatkan oleh kerusakan alam seperti banjir, tanah longsor, kekeringan dan lain sebagainya. Peristiwa tersebut disebabkan beberapa faktor, salah satunya karena ulah manusia. Kenyataannya yang terjadi di lapangan, masih banyak orang yang belum mampu memahami tujuan pembelajaran IPA dengan baik. Masih banyak orang yang tidak bisa menjaga dan melestarikan alam dengan baik. Oleh Karena itu, manusia perlu diberikan pemahaman kembali tentang pembelajaran IPA. Hal ini juga harus diajarkan dari jenjang pendidikan sekolah dasar. Khususnya di Bali daerah pariwisata, karena masih kental dengan tradisi dan budaya atau kearifan lokal. Sehingga implementasi kearifan lokal dalam suatu pembelajaran akan membentuk perilaku dan sikap siswa menjadi lebih baik.

Salah satu kearifan lokal yang dijaga oleh masyarakat di Bali yaitu Tri Hita Karana. Dalam Tri Hita Karana terdapat tiga bagian yang merupakan unsur dari Tri Hita Karana itu sendiri, yaitu parahyangan, pawongan, dan palemahan. Dari ketiga unsur ini diajarkan untuk menghormati Tuhan, sesama manusia, dan lingkungan alam sekitar. Sehingga semua mahkluk hidup diharuskan untuk menghormati dan menghargai sesama ciptaan Tuhan, seperti manusia, hewan, tumbuhan dan segala mahkluk hidup. Konsep Tri Hita Karana sangat cocok diterapkan dalam proses pembelajaran IPA di sekolah dasar.

Konsep Tri Hita Karana yang diterapkan dalam proses pembelajaran IPA akan membentuk prilaku siswa menjadi lebih baik, mampu menghargai Tuhan, menghargai sesama siswa dikelas maupun di sekolah, dan menghargai lingkungan alam. Konsep Tri Hita Karana sudah sejalan dengan tujuan pembelajaran IPA yang mengharapkan manusia mampu memahami rahasia alam disekitar dan mampu menjaga atau melestarikan alam beserta isinya. Dengan menerapkan konsep Tri Hita Karana dalam pembelajaran IPA akan menciptakan suasana belajar yang kondusif dan mampu meningkatkan hasil belajar siswa.

Pada kenyataannya, hasil belajar siswa pada mata pelajaran IPA masih rendah. Berdasarkan hasil observasi yang telah dilaksanakan di Gugus XV Kecamatan Buleleng, menunjukan bahwa wali kelas V dalam mengembangkan model pembelajaran yang inovatif di kelas masih belum optimal. Dalam proses pembelajaran hanya berfokus pada guru yang terus memberikan penjelasan kepada siswa. Sedangkan siswa hanya terpaku untuk mencatat dan mendengarkan penjelasan oleh guru. Masih kurangnya penggunaan lingkungan sekitar sekolah atau halaman sekolah untuk dijadikan objek pembelajaran untuk meningkatkan motivasi siswa dalam belajar. Dalam proses kegiatan belajar masih menjadikan guru sebagai pusat dari pembelajaran, sehingga siswa kurang aktif dalam proses pembelajaran. Kurang aktifnya siswa dapat dilihat dari sikap siswa yang hanya diam dan menunduk pada saat guru memberikan kesempatan kepada siswa untuk bertanya dan menjawab pertanyaan dari guru.

Berdasarkan hasil wawancara dengan guru wali kelas V di Gugus XV Kecamatan Buleleng, didapatkan informasi dari guru wali kelas $\mathrm{V}$ menyatakan bahwa alokasi waktu yang digunakan untuk mengajar dengan menggunakan model menghabiskan banyak waktu. Banyak persiapan yang harus dilakukan oleh guru sebelum melakukan pembelajaran dengan menggunakan model pembelajaran yang inovatif, sehingga mereka lebih praktis menggunakan metode ceramah, memberi tugas agar siswa aktif dan kegiatan diskusi di dalam kerja kelompok.

Hasil observasi dan wawancara diperkuat lagi oleh catatan dokumen persentase ketuntasan hasil UAS IPA pada semester ganjil tahun pelajaran 2017/2018 di SD Gugus XV Kecamatan Buleleng, Kabupaten Buleleng ditemukan masih banyak siswa yang mendapatkan nilai di bawah KKM. Banyaknya siswa yang mendapat nilai di bawah KKM dapat dilihat pada tabel 1.

Tabel 1. Persentase Ketuntasan Hasil Belajar IPA Kelas V di SD Gugus XV Kecamatan Buleleng

\begin{tabular}{ccccccc}
\hline \multirow{2}{*}{ Nama SD } & \multirow{2}{*}{ KKM } & Banyak & \multicolumn{2}{c}{ Mencapai KKM } & \multicolumn{2}{c}{ Belum Mencapai KKM } \\
& & Siswa & Siswa & $\%$ & Siswa & $\%$ \\
\hline SD N 1 Anturan & 70 & 23 & 8 & 34,8 & 15 & 65,2 \\
SD N 2 Anturan & 70 & 33 & 28 & 84,8 & 5 & 15,2 \\
SD N 3 Anturan & 68 & 29 & 20 & 69 & 9 & 31 \\
\hline
\end{tabular}




\begin{tabular}{ccccccc}
\hline \multirow{2}{*}{ Nama SD } & \multirow{2}{*}{ KKM } & Banyak & \multicolumn{2}{c}{ Mencapai KKM } & \multicolumn{2}{c}{ Belum Mencapai KKM } \\
& & Siswa & Siswa & $\%$ & Siswa & $\%$ \\
\hline SD Tri Amerta & 70 & 21 & 7 & 33,3 & 14 & 66,7 \\
SD N 2 Kalibukbuk & 75 & 34 & 28 & 82,4 & 6 & 18,6 \\
SD N 3 Kalibukbuk & 70 & 24 & 19 & 79,2 & 5 & 20,8 \\
SD N 4 Kalibukbuk & 65 & 39 & 23 & 59 & 16 & 41 \\
Jumlah & & 203 & 133 & & 70 & 34,5 \\
Rata-rata & & & & 65,5 & & \\
\hline
\end{tabular}

Berasarkan Tabel 1, dapat dilihat bahwa masih banyaknya sekolah di SD Gugus XV Kecamatan Buleleng yang persentase ketuntasannya dibawah 70\%. Dilihat dari banyaknya siswa yang belum tuntas yaitu sebanyak 70 siswa dari 203 siswa di SD Gugus XV Kecamatan Buleleng adalah 65,5\% siswa mencapai KKM sedangkan 34,5\% siswa masih belum mencapai KKM. Terdapat banyak siswa yang belum mencapai KKM. Terkait temuan tersebut, artinya pembelajaran yang terjadi di SD Gugus XV Kecamatan Buleleng belum optimal.

Hal ini menandakan bahwa dalam proses pembelajaran terjadi kesalahan, baik dalam proses pembelajaran maupun proses yang terkait di sekolah. Terkait temuan di lapangan, maka perlu adanya perubahan dalam proses pembelajaran IPA. Hal Ini disebabkan oleh kurangnya penerapan model pembelajaran yang inovatif lainnya dan memanfaatkan keadaan lingkungan sekitar untuk kegiatan pembelajaran. Agar pembelajaran IPA dapat efektif dan kreatif, maka guru harus bisa menentukan suatu model. Karena model adalah suatu prosedur yang dipakai untuk mencapai tujuan tertentu. Semakin tepat model pembelajaran yang digunakan oleh guru dalam mengajar, diharapkan semakin efektif pada pencapaian tujuan pembelajaran. Salah satu model yang cocok dalam pembelajaran IPA adalah model Student Facilitator and Explaining (SFAE). (Sohimin, 2014) menyatakan, "model pembelajaran student facilitator and explaining merupakan salah satu tipe pembelajaran kooperatif yang menekankan pada struktur khusus yang dirancang untuk memengaruhi pola interaksi peserta didik dan memiliki tujuan untuk meningkatkan penguasaan materi". Model pebelajaran Student Faciliator and Explaining (SFAE) memiliki banyak keunggulan untuk membuat siswa aktif dalam proses pembelajaran dan membuat proses pembelajaran menjadi tidak membosankan. Model pembelajaran ini merupakan model pembelajaran yang dicanangkan untuk mengganti model pembelajaran konvensional dalam pembelajaran IPA. Model pembelajaran Student Facilitator and Explaining (SFAE) dicanangkan mengganti model pembelajaran konvensional karena model ini memberi kesempatan kepada siswa untuk belajar secara aktif, siswa akan menyampaikan materi dengan pemahaman masing-masing. (Kurniasih \& Sani, 2016) menyatakan, langkah-langkah pembelajaran SFAE dapat dilakukan sebagai berikut. (1) Guru menyampaikan kompetensi yang ingin dicapai dalam proses pembelajaran tersebut. (2) Guru menerangkan atau menyajikan garis-garis besar materi pembelajaran. (3) Kemudian memberikan kesempatan siswa untuk menjelaskan kepada siswa lainnya, misalnya melalui bagan atau peta konsep, dan proses ini bisa dilakukan secara bergiliran. (4) Guru menyimpulkan ide atau pendapat dari siswa. (5) Guru menerangkan semua materi yang disajikan sebagai kesimpulan, dan kemudian menutup pelajaran seperti proses yang seharusnya.

Sehingga dengan siswa menjelaskan materi ajar dengan mandiri, pemahaman siswa akan lebih baik dari pada hanya mendengarkan penjelasan guru saja. Hal ini didukung oleh hasil penelitian yang dilakukan oleh (Pawitra, 2013). Dalam penelitiannya menunjukan penerapan model SFAE dalam pembelajaran memungkinkan siswa untuk tahu manfaat dari materi yang dipelajari bagi kehidupannya, aktif dalam kegiatan pembelajaran, menemukan sendiri konsep-konsep yang dipelajari tanpa harus selalu tergantung pada guru, mampu memecahkan masalah-masalah yang berkaitan dengan konsep yang dipelajari, bekerja sama dengan siswa lain, dan berani untuk mengemukakan pendapat. Siswa menjadi lebih tertantang untuk belajar dan berusaha menyelesaikan semua permasalahan IPA yang ditemui, sehingga pengetahuan yang diperoleh akan lebih diingat oleh siswa.

(Saifuddin, 2015) menyatakan bahwa erdasarkan dari hasil data prestasi belajar siswa diatas dapat membuktikan bahwa model pembelajaran Student Facilitator and Explaining (SFE) mampu meningkatkat prestasi belajar siswa. Pembelajaran SFAE memberikan respon yang positif bagi siswa. Hal ini diungkapkan oleh (Mulyani, 2016) yang menyatakan bahwa pembelajaran menggunakan model kooperatif tipe Student Facilitator and Explaining menghasilkan respon yang positif dari para peserta didik. Selain itu pembelajaran model SFAE juga mampu meningkatkan keatifan siswa dalamproses pembelajaran. Hal ini diungkakan oleh (Yanto, 2018) yang mengatakan bahwa proses pembelajaran menggunakan model pembelajaran kooperatif tipe student facilitator and explaining ini dapat 
meningkatkan keterlibatan siswa secara aktif dalam pembelajaran dan dapat meningkatkan hasil belajar siswa.

Dalam model pemelajaran student facilitator and explaining (SFAE) siswa juga akan bekerja dalam kelompok sehingga siswa saling membantu dengan teman lainnya. Siswa juga lebih menghargai dan menghormati sesama teman di kelas. Hal ini sejalan dengan konsep bermasyarakat di Bali yaitu Tri Hita Karana. Sanjaya (2011) menyatakan,"Tri Hita Karana adalah tiga hal yang menyebabkan kebahagian". Agar proses pembelajaran yang dilaksanakan maksimal, maka perlu dipadukan dengan Tri Hita Karana.

Konsep ini sangat berkaitan erat dengan kehidupan masyarakat di Bali. Prinsip masyarakat hidup di Bali masih memegang teguh tradisi dan budaya yang telah diajarkan leluhur. "Tri Hita Karana mengandaikan harmonisnya hubungan manusia dengan Tuhan, sesama manusia, dan juga lingkungan atau alam kehidupan beserta isinya" (Sanjaya, 2011). Perpaduan antara tiga unsur tersebut secara harmonis sebagai landasan untuk terciptanya rasa hidup yang nyaman, tentram, dan damai.

Model pembelajaran Student Facilitator and Explaining (SFAE) berorientasi Tri Hita Karana merupakan model pembelajaran yang melaksanakan pembelajaran dengan disertai terbentuknya kelompok agar terjadi hubungan harmonis dengan sesama teman dan menjaga kebersihan lingkungan kelas. Dengan menghargai lingkungan kelas dan menghormati sesama teman berarti mencintai ciptaan Tuhan, sehingga dengan hubungan yang harmonis ini seluruh siswa berhasil mencapai tujuan pembelajaran. Dalam proses pembelajaran yang baik bisa menerapkan beberapa nilai-nilai kearifan lokal yang membantu siswa agar mampu meningkatkan pengetahuan, menjaga prilaku, dan sikap dalam kehidupan sehari-hari. Dengan memasukan nilai-nilai sikap saling menghargai dan saling menghormati yang terkandung dalam ajaran Tri Hita Karana ke dalam proses pembelajaran IPA. Dengan menerapkan nilai-nilai tersebut, siswa atau peserta didik akan menjadi pribadi yang baik, mampu menjalin hubungan yang harmonis dengan Tuhan, teman, dan lingkungannya. Dibandingkan dengan proses pembelajaran yang dibelajarkan tidak menggunakan model student facilitator and explaining (SFAE) berorientasi tri hita karana. Siswa hanya terpaku dengan penjelasan yang diberikan oleh guru, hanya mencatat dan menjadi pendengar. Sehingga proses berpikir siswa yang tidak dibelajarkan menggunakan model student facilitator and explaining (SFAE) berorientasi tri hita karana mengakibatkan aktivitas siswa di dalam proses pembelajaran kurang. Yang mengakibatkan proses pembelajaran hanya berpusat kepada guru. Pemahaman siswa terhadap materi juga akan terganggu karena kurangnya aktivitas siswa di dalam proses pembelajaran, yang mengakibatkan hasil belajar siswa menurun.

Dengan permasalahan yang diuraikan di atas, maka tujuan diadakan penelitian ini yaitu untuk mengetahui perbedaan yang signifikan pada hasil belajar IPA siswa yang dibelajarkan dengan model Student Facilitator and Explaining (SFAE) Berorientasi Tri Hita Karana dan siswa yang dibelajarkan tidak dengan model Student Facilitator and Explaining (SFAE) Berorientasi Tri Hita Karana pada kelas V Sekolah Dasar di Gugus XV Kecamatan Buleleng Tahun Pelajaran 2017/2018.

Berdasarkan proses pembelajaran yang telah diuraikan di atas, dapat dikatakan bahwa model pembelajaran Student Facilitator and Explaining (SFAE) Berorientasi Tri Hita Karana diduga mampu meningkatkan hasil belajar siswa. Untuk membuktikannya, dilakukanlah penelitian eksperimen yang berjudul "Pengaruh Model Student Facilitator and Explaining (SFAE) Berorientasi Tri Hita Karana terhadap Hasil Belajar IPA Siswa Kelas V Sekolah Dasar di Gugus XV Kecamatan Buleleng Tahun Pelajaran 2017/2018".

\section{Metode}

Penelitian ini dilaksanakan di SD Gugus XV Kecamatan Buleleng, yakni di kelas V SD Negeri 2 Kalibukbuk dan di kelas V SD Negeri 3 Anturan. Penelitian ini dilakukan pada semester 2 Tahun Pelajaran 2017/2018. Jenis penelitian ini adalah penelitian eksperimen semu. Penelitian ini mengunakan rancangan non-equivalent post-test only group design. Desain penelitian ini dipilih karena eksperimen tidak mungkin mengubah kelas yang sudah ada. Dalam desain ini terdapat dua kelompok yang dipilih secara acak. Kelompok pertama yang diberikan perlakuan (X) disebut dengan kelompok eksperimen, sedangkan kelompok yang tidak mendapatkan perlakuan disebut kelompok kontrol. Secara prosedural desain penelitian non-equivalent post-test only group design disajikan dalam tabel 2.

Tabel 2. Desain Penelitian Non-equivalent Post-test Only Group Design

\begin{tabular}{ccc}
\hline Kelas & Perlakuan & Post-Test \\
\hline Eksperimen & $\mathrm{X}$ & $\mathrm{O}_{1}$ \\
Kontrol & - & $\mathrm{O}_{2}$ \\
\hline
\end{tabular}

Sumber: (diadaptasi dari Agung:2014 
Berdasarkan Tabel 2, diketahui bahwa perlakuan hanya diberikan kepada kelas ekperimen. Pusat perhatian dalam penelitian ini terletak pada kelas eksperimen yang diberikan perlakuan berupa model Student Facilitator and Explaining (SFAE) berorientasi Tri Hita Karana dan kelompok kontrol tidak diberikan perlakuan. Pada kelas eksperimen dan kelas kontrol diberikan post-test setelah mengalami perlakuan.

Variabel yang terlibat dalam peneliatan ini adalah sebagai berikut. (1) variabel bebas dalam penelitian ini adalah model pembelajaran Student Facilitator and Explaining (SFAE) berorientasi Tri Hita Karana yang diterapkan pada kelas eksperimen dan kelompok kontrol tidak diberikan perlakuan. (2) variabel terikat dalam penelitian ini adalah hasil belajar IPA siswa kelas V di SD Gugus XV Kecamatan Buleleng.

Populasi dalam penelitian ini adalah seluruh siswa kelas V di SD Gugus XV Kecamatan Buleleng yang menerapkan KTSP berjumlah 203 orang siswa. Populasi penelitian sebelum mendapat perlakuan dan sebelum dipilih untuk dijadikan sampel harus dilakukan uji kesetaraan terlebih dahulu agar dapat diketahui seluruh sekolah di dalam Gugus XV Kecamatan Buleleng sudah setara. Uji yang digunakan untuk melihat kesetaraan tersebut menggunakan uji ANAVA A. Dan nilai yang digunakan adalah nilai hasil UAS IPA semester 1 kelas V di Gugus XV Kecamatan Buleleng. Dari hasil analisis tersebut, maka dapat ditarik kesimpulan bahwa hasil belajar IPA siswa kelas V SD Gugus XV Kecamatan Buleleng Tahun Pelajaran $2017 / 2018$ adalah setara.

Teknik sampling yang digunakan dalam penelitian ini adalah teknik Simple Random Sampling. Teknik simple random sampling ini semua kelompok dalam populasi memiliki hak yang sama untuk dijadikan sampel. Terlebih dahulu dilakukan uji kesetaraan dan sudah didapatkan bahwa hasil seluruh sekolah di Gugus XV Kecamatan Buleleng sudah setara. Setelah dilakukan pengundian dalam populasi tersebut, yang menjadi sampel penelitian adalah SDN 2 Kalibukbuk dan SDN 3 Anturan. Berdasarkan hasil pengundian kedua, untuk menentukan kelas eksperimen dan kelas kontrol, didapatkan hasil yang menjadi kelas eksperimen adalah SDN 2 Kalibukbuk yang berjumlah 34 orang siswa dan SDN 3 Anturan berjumlah 29 orang siswa sebagai kelas kontrol. Kelas eksperimen akan diberikan perlakuan dengan menggunakan model Student Facilitator and Explaining (SFAE) berorientasi Tri Hita Karana. Sedangkan kelas kontrol dibelajarkan tidak dengan menggunakan model Student Facilitator and Explaining (SFAE) berorientasi Tri Hita Karana.

Data yang dikumpulkan dalam penelitian ini adalah hasil belajar IPA siswa kelas V SD di Gugus XV Kecamatan Buleleng. Metode pengumpulan data yang digunakan untuk memperoleh hasil belajar ranah kognitif siswa adalah dengan metode tes, dengan menggunakan tes objektif. Tes hasil belajar berfungsi untuk mengumpulkan data hasil belajar IPA siswa setelah mengikuti proses pembelajaran.

Sebelum digunakan sebagai post-test, tes tersebut diuji cobakan terlebih dahulu untuk mencari validitas butir, reliabilitas, daya beda dan tingkat kesukarannya. Uji coba tersebut dimaksudkan untuk memperoleh gambaran mengenai kelayakan instrumen digunakan sebagai instrumen penelitian. Berdasarkan hasil perhitungan validitas isi diperoleh 40 butir soal yang relevan dari 40 soal yang diujikan, sehingga diperoleh hasil sebesar 1,00. Hasil validitas isi tes termasuk dalam kriteria sangat tinggi. Berdasarkan hasil uji validitas butir tes pada taraf signifikansi 5\%, diperoleh 36 butir tes yang valid dan 4 soal yang tidak valid. Berdasarkan hasil uji realibilitas tes, diperoleh koefisien realibilitas sebesar 0,844. Hal ini berarti, tes yang diuji termasuk ke dalam kriteria sangat tinggi. Berdasarkan hasil perhitungan daya beda, diperoleh 36 soal memenuhi kriteria tes standar dari 36 butir soal yang valid. Berdasarkan hasil perhitungan dari 36 tes yang valid, diperoleh hasil perhitungan 2 soal tergolong sukar, 31 soal tergolong sedang, dan 3 soal tergolong mudah. Hasil perhitungan tingkat kesukaran perangkat tes diperoleh hasil sebesar 0,602 yaitu termasuk kedalam kriteria sedang. Dari hasil perhitungan uji validitas isi, validitas butir, reliabilitas, daya beda dan tingkat kesukaran, dipilih 30 soal yang digunakan sebagai intsrumen post-test Pada penelitian ini post-test akan diberikan diakhir penelitian. Teknik analisis data yang digunakan dalam penelitian ini adalah analisis statistik deskriptif dan analisis statistik inferensial (uji-t). Analisis deskriptif, yang artinya bahwa data dianalisis dengan mencari mean, median, modus, standar deviasi, varians. Dalam penelitian ini data disajikan dalam bentuk grafik poligon. Analisis statistik inferensial yaitu menggunakan uji-t sampel independent (tidak berkorelasi) dengan rumus polled varians.

\section{Hasil dan Pembahasan}

Deskripsi data hasil penelitian meliputi deskripsi data penelitian post- test kelompok eksperimen dan deskripsi data penelitian post-test kelompok kontrol. Data hasil penelitian yang dianalisis adalah data berbentuk skor. Penelitian ini dilaksanakan di kelas V SD Gugus XV Kecamatan Buleleng pada semester genap tahun pelajaran 2017/2018, yang dilakukan sebanyak 8 kali pertemuan, 7 kali pertemuan kegiatan pembelajaran dan 1 kali pertemuan untuk melaksanakan post-test. 
Berdasarkan tes hasil belajar IPA yang diberikan kepada kedua kelas setelah 7 kali proses pembelajaran, maka diperoleh data hasil belajar IPA siswa yang dilaksanakan setelah pembelajaran (posttest) pada tabel 3.

Tabel 3. Statistik Deskriptif Hasil Penelitian Kelas Eksperimen dan Kelas Kontrol

\begin{tabular}{lcl}
\hline Statistik & Kelompok Eksperimen & Kelompok Kontrol \\
\hline Banyak Sampel & 34 & 29 \\
Mean & 23,12 & 16,21 \\
Median & 23,58 & 15,67 \\
Modus & 24,18 & 15 \\
Varians & 15,93 & 16,71 \\
Standar Deviasi & 3,99 & 4,09 \\
Skor Maksimum & 29 & 25 \\
Skor Minimum & 14 & 9 \\
Rentangan & 15 & 16 \\
\hline
\end{tabular}

Berdasarkan Tabel 3, selanjutnya data hasil belajar IPA kelompok eksperimen dan kelompok kontrol disajikan dalam bentuk grafik poligon seperti gambar 1 dan gambar 2.

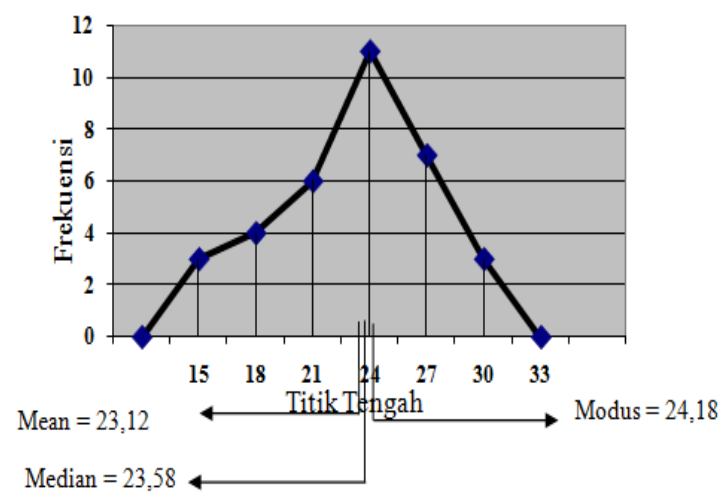

Gambar 1. Grafik Poligon Data Hasil Belajar IPA Kelompok Eksperimen

Berdasarkan gambar 1, dapat diketahui bahwa mean lebih kecil dari median, dan median lebih kecil dari modus, $M o>M d>M(24,18>23,58>23,12)$. Jika dilihat gambar grafik poligon merupakan kurva juling negatif. Ini menunjukan sebagian besar skor cenderung tinggi.

Untuk mengetahui kualitas variabel hasil belajar IPA pada kelompok eksperimen, data skor ratarata hasil belajar IPA siswa dikonversikan menggunakan kriteria rata-rata ideal $\left(\mathrm{X}_{\mathrm{i}}\right)$ dan standar deviasi ideal $\left(\mathrm{SD}_{\mathrm{i}}\right)$ maka diperoleh hasil konversi. Skor rata-rata kelompok eksperimen berada pada kategori sangat tinggi yaitu sebesar 23,12 (terletak antara $22,5 \leq \bar{X}_{\leq 30}$ ).



Gambar 2. Grafik Poligon Data Hasil Belajar IPA Kelompok Kontrol 
Berdasarkan gambar 2, dapat diketahui bahwa mean lebih besar dari median, dan median lebih besar dari modus, Mo $<\mathrm{Md}<\mathrm{M}(15<15,67<16,21)$. Jika dilihat gambar grafik poligon merupakan kurva juling positif. Ini menunjukan sebagian besar skor cenderung rendah.

Untuk mengetahui kualitas variabel hasil belajar IPA pada kelompok kontrol, data skor rata-rata hasil belajar IPA siswa dikonversikan menggunakan kriteria rata-rata ideal $\left(\mathrm{X}_{\mathrm{i}}\right)$ dan standar deviasi $\left(\mathrm{SD}_{\mathrm{i}}\right)$ maka diperoleh hasil konversi. Skor rata-rata kelompok kontrol berada pada kategori sedang yaitu 16,21 (terletak antara $12,5 \leq \bar{X}_{\leq 17,5)}$.

Sebelum melakukan uji hipotesis, terlebih dahulu dilakukan uji prasyarat analisis data yaitu uji normalitas dan uji homogenitas. Berdasarkan perhitungan data hasil belajar IPA dengan menggunakan rumus Chi-Kuadrat $\left(\mathrm{X}^{2}\right)$, diperoleh $\mathrm{X}^{2}$ hit kelompok eksperimen adalah 2,938 dan $\mathrm{X}^{2}$ tab dengan taraf signifikansi $5 \%$ adalah 7,815. Hal ini berarti, $\mathrm{X}^{2}$ hit lebih kecil dari $\mathrm{X}^{2}$ tab sehingga data hasil belajar IPA kelompok eksperimen berdistribusi normal.

Hasil perhitungan data hasil belajar IPA dengan menggunakan rumus Chi-Kuadrat (X²), diperoleh $\mathrm{X}^{2}$ hit kelompok kontrol adalah 3,1537 dan $\mathrm{X}_{\text {tab }}$ dengan taraf signifikansi 5\% adalah 7,815. Hal ini berarti, $\mathrm{X}^{2}$ hit lebih kecil dari $\mathrm{X}^{2}$ tab sehingga data hasil belajar IPA kelompok kontrol berdistribusi normal.

Uji homogenitas varians dilakukan dengan menggunakan uji Fisher. Uji homogenitas dilakukan untuk mengetahui apakah kedua varians data bersifat homogen. Dari hasil perhitungan yang dilakukan, diperoleh $\mathrm{F}_{\text {hit }}=1,049$, sedangkan $\mathrm{F}_{\text {tab }}$ dengan $\mathrm{db}_{\text {pembilang }}=28$, db $\mathrm{b}_{\text {penyebut }}=33$ dan taraf signifikansi $5 \%$ adalah 1,8194. Hal ini berarti $F_{\text {hit }}=1,049<\mathrm{F}_{\mathrm{tab}}=1,8194$ sehingga hasil belajar IPA kedua kelompok homogen.

Pengujian hipotesis dalam dalam penelitian ini menggunakan uji-t dengan rumus polled varians. Data yang digunakan yaitu skor rata-rata $\left(\bar{X}_{1}\right)$ kelompok eksperimen sebesar 23,12 dengan varians $\left({ }^{s_{1}{ }^{2}}\right)$ sebesar 15,93. Pada kelompok kontrol diperoleh skor rata-rata $\left(\bar{X}_{2}\right)$ sebesar 16,21 dengan varians $\left({ }^{s_{2}}{ }^{2}\right)$ sebesar 16,71 . Hasil perhitungan setelah dilakukan analisis menggunakan uji-t, maka diperoleh nilai $t_{\text {hit }}$ sebesar 6,821. Untuk mengetahui nilai tab dengan derajat kebebasan $(\mathrm{dk})=(34+29)-2=61$ dan taraf signifikansi $5 \%$ diperoleh nilai $t_{t a b}=1,99962$. Hasil uji hipotesis dengan uji-t dapat dilihat pada tabel 4.

Tabel 4. Hasil Perhitungan Uji Hipotesis dengan Uji-t

\begin{tabular}{cllllll}
\hline Kelompok & $\mathbf{n}$ & Varians & Db & thitung $_{\text {tabel }}$ & Tesimpulan & Kesimp \\
\hline Eksperimen & 34 & 15,93 & 61 & 6,821 & 1,99962 & $\mathrm{H}_{0}$ ditolak dan \\
Kontrol & 9 & 16,71 & & & $\mathrm{H}_{1}$ diterima \\
\hline
\end{tabular}

Berdasarkan Tabel 4, dengan membandingkan nilai $t_{\text {hit }}$ dan $t_{\text {tab }}$ diperoleh perbandingan $t_{\text {hit }}>t_{\text {tab }}$, ini menunjukan berarti $\mathrm{H}_{0}$ ditolak dan $\mathrm{H}_{1}$ diterima. Hal ini menunjukan hasil belajar IPA siswa yang dibelajarakan dengan model Student Facilitator and Expalining (SFAE) berorientasi Tri Hita Karana lebih baik daripada hasil belajar IPA siswa yang dibelajarkan tidak dengan model Student Facilitator and Explaining (SFAE) berorientasi Tri Hita Karana.

Sebelum dilakukan uji hipotesis dengan menggunakan analisis uji-t, terlebih dahulu dilakukan uji prasyarat yang meliputi uji normalitas sebaran data dan uji homogenitas varians. Dari hasil perhitungan diketahui bahwa sebaran data pada kedua kelompok berdistribusi normal dan memiliki varians yang homogen. Karena data pada kelomok eksperimen dan kelompok kontrol telah memenuhi semua prasyarat, selanjutnya dilakukan analisis dengan menggunakan uji-t.

Hasil perhitungan setelah dilakukan analisis menggunakan uji-t, maka diperoleh thit sebesar 6,821. Nilai $t_{t a b}$ dengan derajat kebebasan $(\mathrm{dk})=(34+29)-2=61$ dan taraf signifikansi $5 \%$ diperoleh nilai $t_{\text {tab }}=$ 1,99962. Dengan membandingkan nilai $t_{\text {hit }}$ dan $t_{\text {tab }}$ diperoleh perbandingan $t_{\text {hit }}>t_{t a b}$, ini menunjukan berarti $\mathrm{H}_{0}$ ditolak dan $\mathrm{H}_{1}$ diterima. Hal ini menunjukan hasil belajar IPA siswa yang dibelajarakan dengan model Student Facilitator and Expalining (SFAE) berorientasi Tri Hita Karana lebih baik daripada hasil belajar IPA siswa yang dibelajarkan tidak dengan model Student Facilitator and Explaining (SFAE) berorientasi Tri Hita Karana.

Hasil analisis data hasil belajar IPA kedua kelompok baik kelompok eksperimen yang dibelajarkan dengan menggunakan model pembelajaran Student Facilitator and Expalining berorientasi Tri Hita Karana maupun kelompok kontrol yang dibelajarkan tidak dengan menggunakan model pembelajaran Student Facilitator and Explaining berorientasi Tri Hita Karana memiliki perbedaan skor rata-rata hasil belajar IPA. Pada kelompok eksperimen lebih besar dibandingkan dengan kelompok kontrol $(23,12>16,21)$. Adanya perbedaan perolehan skor rata-rata tersebut menunjukan bahwa model pembelajaran Student Facilitator and Explaining berorientasi Tri Hita Karana memberikan pengaruh yang positif terhadap hasil belajar IPA siswa. Hal ini disebabkan karena model pembelajaran Student Facilitator and Explaining yang 
menjadikan siswa lebih aktif dan setiap siswa diberikan kesempatan untuk mempersentasikan atau menjelaskan materi didepan kelas, sehingga siswa akan memahami materi dengan lebih baik. perilaku siswa di dalam proses pembelajaran menjadi sangat baik dan menciptakan kondisi yang kondusif dengan diorientasikan kearifan lokal yaitu Tri Hita Karana.

Model pembelajaran Student Facilitator and Explaining terdidiri dari beberapa kegiatan pembelajaran yaitu penyajian informasi, pembentukan kelompok dan diskusi, penyusunan LKS, kegiatan persentasi dan tanya jawab, dan menyimpulkan materi di akhir pembelajaran. Pada tahap pertama, penyajian informasi mengarahkan siswa dalam menjawab pertanyaan-pertanyaan yang sifatnya menggali dalam kegiatan apersepsi, sehingga terjadi proses berpikir yang mengaitkan pengetahuan sikap siswa dan pengalamannya dengan pengetahuan baru yang sedang dipelajari. Terbukti dari antusias siswa dengan menjawab pertanyaan dalam apersepsi dan siswa mencermati materi yang dipaparkan guru. Tahapan kedua, dalam pembentukan kelompok dipilih satu orang sebagai fasilitator yang memiliki kemampuan lebih dibandingkan teman yang ada di dalam kelompok. Dalam kegiatan diskusi, tugas dari fasilitator untuk membantu siswa yang kesulitan dalam memahami materi. Dipilihnya siswa sebagai fasilitator karena hubungan baik antara teman di kelas menjadikan siswa tidak canggung dalam bertanya tentang hal yang dianggap sulit. Dengan menjadikan siswa sebagai fasilitator, akan terjadi komunikasi yang lebih baik dan membuat pemahaman siswa lebih baik. tahap ketiga, penyusunan LKS untuk mengarahkan siswa dalam mengerjakan LKS sehingga dapat mengembangkan konsep yang dimiliki mereka dan dapat dilihat ketika siswa mengumpulkan informasi sebanyak-banyaknya dan terbuka terhadap pendapat orang lain melalui mendengar atau bertukar pendapat dalam satu kelompok. Pada tahap keempat, kegiatan persentasi dan tanya jawab ini mengarahkan siswa kedalam penyampaian hasil diskusi dan menyiapkan pertanyaan jika masih ada yang belum mengerti. Hal ini dapat dilihat ketika siswa menyampaikan hasil diskusi tersebut dan siswa memberi saran atau pertanyaan ketika teman selesai persentasi di depan kelas. Tahap kelima yaitu menyimpulkan, dalam tahap ini siswa dapat berpikir memaknai pengalaman, mengevaluasi informasi, melahirkan gagasan baru dan memecahkan masalah. Terlihat dari antusias siswa dalam menyampaikan materi pembelajaran. Dengan pengunaan model pembelajaran SFAE siswa menjadi lebih antusias dalam belajar dan mampu meningkatkan pemahaman siswa di kelas eksperimen. Temuan penelitian tersebut sejalan dengan pendapat Sohimin (2014) yang menyatakan, "Model pembelajaran student facilitator and explaining merupakan salah satu tipe pembelajaran kooperatif yang menekankan pada struktur khusus yang dirancang untuk memengaruhi pola interaksi peserta didik dan memiliki tujuan untuk meningkatkan penguasaan materi".

Implementasi Tri Hita Karana di dalam proses pembelajaran adalah dengan mengajak siswa untuk selalu melakukan kegiatan yang mencerminkan parahyangan yaitu hubungan yang harmonis dengan Tuhan yang pelaksanaannya melalui proses persembahyangan atau berdoa sebelum dan sesudah pembelajaran, sehingga siswa menjadi nyaman, mendapatkan rasa percaya diri, dan menambah nilai spiritual siswa, sehingga dalam proses pembelajaran tanpa disuruh lagi, mereka terbiasa melakukan persembahyangan sebelum dan sesudah pembelajaran. Selanjtnya pawongan yaitu hubungan yang harmonis dengan sesama manusia, penerapan nilai pawongan dalam proses pembelajaran adalah dengan menghargai guru yang sedang menjelaskan materi, menghargai teman yang sedang persentasi di depan kelas dan menghormati pendapat teman yang lain, hal ini berdampak pada perilaku siswa yang menjadi lebih toleran dan menghargai sesama teman maupun guru. Dan yang terakhir palemahan yaitu hubungan yang harmonis dengan lingkungan, penerapan nilai palemahan yaitu siswa menjaga lingkungan kelas dengan cara membersihkan ruang kelas sebelum dan sesudah pembelajaran, tidak membuang sampah sembarangan untuk menjaga lingkungan yang nantinya akan berdampak pada sikap siswa yang mampu menjaga kebersihan lingkungan baik di sekolah, rumah maupun lingkungan masyarakat yang lebih luas. Model pembelajaran student facilitator and explaining berorientasi Tri Hita Karana tidak hanya memberikan peningkatan dalam hasil belajar siswa namun dapat memperbaiki karakter dan perilaku siswa.

Impelemntasi nilai-nilai Tri Hita Karana ini diperkuat oleh Wiana (2007) menyatakan, Mencapai kehidupan yang bahagia dengan melakukan hubungan yang harmonis dengan Tuhan, dengan sesama manusia dan lingkungan alam inilah yang disebut Tri Hita Karana. Membangun hubungan yang harmonis pada Tuhan dengan Bhakti, pada sesama manusia dengan dasar punia, dan dengan lingkungan alam dengan "asih".

Dengan menerapkan semua nilai-nilai Tri Hita Karana di dalam proses pembelajaran akan tercipta suasana kebahagiaan atau menjadikan pembelajaran yang kondusif, siswa nyaman dalam belajar, dan meningkatkan pengetahuan siswa.

Beda halnya dengan siswa yang dibelajarkan tidak dengan menggunakan model student facilitator and explaining berorientasi tri hita karana, dalam pembelajaran guru lebih mendominasi proses pembelajaran sehingga pembelajaran hanya berpusat pada guru. interaksi siswa dan guru bersifat satu 
arah, sehingga siswa hanya bersifat pasif dalam mengikuti proses pembelajaran. Dalam proses mengajar guru masih dominan menggunakan metode ceramah. Sehingga siswa kurang antusias dalam proses pembelajaran. Temuan ini sejalan dengan pendapat Sumantri; Mulyani; Johar Permana (1999) menyatakan, bahwa metode ceramah adalah penyajian pelajaran oleh guru dengan cara memberikan penjelasan secara lisan kepada peserta didik.

Penelitian ini diperkuat dengan penelitian sejenis yang dilakukan oleh Pawitra (2013) yang menyatakan bahwa penerapan model SFAE dalam pembelajaran memungkinkan siswa untuk tahu manfaat materi yang dipelajari bagi kehidupannya, aktif dalam kegiatan pembelajaran, menemukan sendiri konsep-konsep yang dipelajari tanpa harus selalu tergantung dengan guru, bekerja sama dengan siswa lain, dan berani untuk mengemukakan pendapat. Siswa

\section{Simpulan dan Saran}

Berdasarkan hasil penelitian dan analisi data yang telah dilakukan, dapat disimpulkan bahwa terdapat perbedaan yang signifikan hasil belajar IPA siswa yang dibelajarkan melalui model Student Facilitator and Explaining (SFAE) berorientasi Tri Hita Karana dan siswa yang dibelajarkan tidak melalui model Student Facilitator and Explaining (SFAE) berorientasi Tri Hita Karana pada kelas V Sekolah Dasar di Gugus XV Kecamatan Buleleng Tahun Pelajaran 2017/2018. Hal ini dapat dilihat dari hasil uji-t diperoleh nilai $t_{\text {hit }}=6,821>$ nilai $t_{\text {tab }}=1,99962$. Adanya perbedaan yang signifikan menunjukan bahwa model Student Facilitator and Explaining (SFAE) berorientasi Tri Hita Karana berpengaruh positif terhadap hasil belajar IPA siswa kelas V Sekolah Dasar di Gugus XV Kecamatan Buleleng Tahun Pelajaran $2017 / 2018$.

Berdasarkan hasil penelitian ini, maka dapat diajukan beberapa saran sebagai tindak lanjut dari penelitian ini adalah sebagai berikut. Guru disarankan untuk lebih mengembangkan pembelajaran dengan menggunakan berbagai macam model pembelajaran dan media yang inovatif, khususnya dalam mata pelajaran IPA. Salah satu model pembelajaran yaitu Student Facilitator and Explaining berorientasi Tri Hita Karana sehingga dapat mengoptimalkan hasil belajar IPA siswa. Pihak sekolah diharapkan agar selalau mendukung penggunaan model pembelajaran inovatif dalam pembelajaran. Salah satunya penggunaan model pembelajaran Student Facilitator and Explaining berorientasi Tri Hita Karana sehingga siswa lebih aktif dalam proses pembelajaran. Peneliti lain agar meneruskan penelitian ini untuk menjangkau masalah-masalah lain yang belum ditemukan dalam penelitian ini, sehingga menjadi penelitian yang sempurna dari penelitian ini.

\section{Daftar Rujukan}

Kurniasih, I., \& Sani, B. (2016). Ragam Pengembangan Model Pembelajaran. Kata Pena.

Mulyani, E. (2016). Pengaruh Penggunaan Model Pembelajaran Kooperatif Tipe Student Facilitator and Explaining Terhadap Pemahaman Matematik Peserta Didik. Jurnal Penelitian Pendidikan Dan Pengajaran Matematika, 2(1), 29-34.

Pawitra, P. M. (2013). Pengaruh Model Pembelajaran Student Facilitator and Explaining Berbantuan Media Mind Mapping Terhadap Penguasaan Konsep IPA Siswa Kelas IV SDN 1 Sangsit. Jurnal PGSD.

Saifuddin, A. (2015). Penerapan Model Pembelajaran Student Facilitator and Explaining (SFAE) dengan Menggunakan Peta Konsep Untuk Meningkatkan Keaktifan dan Prestasi Belajar Siswa Pada Mata Pelajaran Ekonomi Kelas X Lintas Minat Ekonomi di SMA Negeri 02 Batu. JPE, 8(1).

Sanjaya, P. (2011). Filsafat Pendidikan Agama Hindu. Surabaya: Paramitha.

Sohimin, A. (2014). 68 Model Pembelajaran Inovatif dalam Kurikulum 2013. Yogyakarta: AR-RUZZ MEDIA.

Sumantri; Mulyani; Johar Permana. (1999). Strategi Belajar Mengajar. Singaraja: Undiksha Press.

Virani, I. A. D., Riastini, I. P. N., \& Suarjana, I. M. (2016). Deskripsi sikap sosial pada siswa kelas 4 SDN Panarukan Kecamatan Buleleng Kabupaten Buleleng. E-Journal PGSD Universitas Pendidikan Ganesha, 4(1). Retrieved from https://ejournal.undiksha.ac.id/index.php/JJPGSD/article/view/7699/5251

Wiana, I. K. (2007). Tri Hita Karana Menurut Konsep Hindu. Surabaya: Paramitha. 
Yanto, Y. (2018). Penerapan Model Pembelajaran Kooperatif Tipe Student Facilitator and Explaining Terhadap Hasil Belajar Matematika Siswa. Jurnal Pendidikan Matematika, 1(1). 